\title{
Działalność oświatowa polskich towarzystw na Górnym Śląsu na przełomie XIX i XX stulecia
}

\author{
The Educational Activity \\ of Polish Societies in Upper Silesia \\ at the Turn of the $19^{\text {th }}$ and the $20^{\text {th }}$ Centuries
}

\begin{abstract}
ABSTRAKT
Na przełomie XIX i XX wieku na Górnym Ślqsku rozpoczął się rozwói organizacji polskich. Zamieszkała w tym regionie ludność polskojęzyczna była pozbawiona możliwości edukacji w ięzyku ojczystym. Dlatego organizacje społeczno-kulturalne podejmowały działania kompensujqce brak szkoły polskiej oraz rozbudzajqce poczucie przynależności narodowej mieszkańców regionu. W okresie od roku 1899 do 1914 było ich ponad 200. Stawiały sobie jako cel główny obronę polskości na terenach zamieszkałych przez ludność polskojęzycznq. Realizowano to poprzez upowszechnianie wiedzy, inspirowanie różnych form pracy kulturalnej i oświatowej. Do szczególnie popularnych można zaliczyć akcje odczytowe, prowadzone przez wszystkie organizacje polskie, kursy ięzyka polskiego. Na uwage zasługuje też dbałość o rozwój czytelnictwa wśród ludności polskiej, poprzez zakładanie polskich biblioteczek w różnych miejscowościach Śląska Opolskiego. Młodzież preferowała uczestnictwo w teatrach amatorskich, które w okresie zimowym wystawiały różne sztuki teatralne.
\end{abstract}

StOWA KLUCZOWE praca kulturalno-oświatowa, organizacje polskie, formy pracy oświatowej, upowszechnianie kultury polskiej, Górny Ślqqsk

KEYWORDS

cultural and educational work, Polish organizations, forms of educational work, popularization of Polish culture, Upper Silesia

SPI Vol. 19, 2016/2

ISSN 2450-5358

e-ISSN 2450-5366

DOI: 10.12775/SPI.2016.2.002

Artykuły i rozprawy 
Organizowano wycieczki do Krakowa, Częstochowy, a w czasie karnawału odbywały się zabawy towarzyskie. $W$ ten sposób przeciwstawiano się wpływom niemieckim. W artykule przedstawiono niektóre organizacje i formy ich pracy kulturalno-oświatowej.

\section{ABSTRACT}

At the turn of the $19^{\text {th }}$ and the $20^{\text {th }}$ centuries in Upper Silesia, the development of Polish organizations began. The Polish-speaking population inhabiting the region were deprived of the possibility of being educated in their mother tongue. Therefore, the socio-cultural organizations undertook actions to compensate for the lack of Polish schools, as well as ones which were meant to revive the feeling of national belonging among the native inhabitants of the region. In the period between 1899 and 1914 there were over 200 of them and their main objective was to defend and preserve the Polish character in the areas inhabited by the Polish-speaking population. It was realized through popularizing knowledge and inspiring various forms of cultural and educational work. The particularly popular actions comprised lectures, which were run by all the Polish organizations, as well as courses of the Polish language. Attention should also be paid to the concern for the development of readership among the Polish population, which manifested itself in setting up Polish libraries in various places of Opole Silesia. The young preferred to take part in activities of amateur theatres which in the winter season - staged different plays. Excursions to Krakow and Częstochowa were organized, while community parties were held during the carnival season and in this way German influences were opposed. The article presents some of the organizations and forms of their cultural and educational work.

\section{Wstęp}

Działalność oświatowa organizacji społeczno-kulturalnych w XIX i początkach XX wieku w wielu regionach ziem polskich kompensowała braki w wykształceniu dzieci, młodzieży i osób dorosłych. Ich geneza była związana z czynnikami społeczno-gospodarczymi i narodowowyzwoleńczymi. Te ostatnie wyrażały się w dążeniu do zachowania polskości pod zaborami oraz wyzwolenia narodowego. 
Przykładem tego są działania oświatowe prowadzone na Śląsku, regionie, który najwcześniej - bo już w XIV wieku - znalazł się pod obcym panowaniem. Początkowo należał do Czech, potem Austrii, a od 1740 roku znalazł się w obrębie państwa pruskiego.

Problematyka funkcjonowania towarzystw społeczno-oświatowych była podejmowana rzadko przez historyków, natomiast opracowań historyków wychowania $\mathrm{z}$ tego zakresu brakuje. Dlatego też interesujące stało się poszukiwanie odpowiedzi na pytanie związane z działalnością oświatową realizowaną przez towarzystwa społeczne na Górnym Śląsku. Ważne były formy pracy kierowane zarówno do młodego pokolenia, jak i dorosłych oraz ich oddźwięk wśród społeczności tego regionu. Podstawą do przygotowania poniższego tekstu stały się materiały źródłowe znajdujące się w zasobach Biblioteki Instytutu Śląskiego w Opolu, czasopiśmiennictwo tamtego okresu, jak i opracowania.

Rozwijające się na Górnym Śląsku w XIX wieku górnictwo węgla kamiennego, rudy żelaza i cynku oraz hutnictwo w porównaniu do innych regionów Niemiec było bardzo zacofane. Peryferyjne położenie wywoływało trudności w zbycie produktów przemysłowych, zarówno na pobliskich obszarach zaboru rosyjskiego i austriackiego otoczonych granicami celnymi, jak i na oddalonych rynkach zbytu w Niemczech środkowych i północnych.

$\mathrm{Z}$ rozwojem przemysłu związane były przeobrażenia społeczne. Górny Śląsk zamieszkiwała ludność niemiecka i polskojęzyczna. Według spisu z 1910 roku na tych terenach żyło 613 tys. Niemców, a 581 tys. posługiwało się językiem polskim (gwarą śląską). Górnoślązacy polskojęzyczni mieszkali głównie na wsiach, a w miastach występowała przewaga Niemców.

W okresie od 1871 do 1910 roku liczba mieszkańców w regionie wzrosła o 69\% i wyniosła $1270000^{1}$. W II połowie XIX wieku do górnośląskiego okręgu przemysłowego napłynęła znaczna fala ludności z zaboru austriackiego i rosyjskiego. Był to element etnicznie polski, który wywarł znaczący wpływ na rozwój świadomości narodowej robotników. Cechą charakterystyczną stosunków społecznych była zbieżność podziału klasowego z podziałem narodowościowym.

1 K. Jonca, Polityka socjalna Niemiec w przemyśle ciężkim Górnego Ślaska, Katowice 1966, s. 63-65. 
Polacy byli rolnikami i robotnikami, a Niemcy - właścicielami i pracodawcami.

Poczynając od zainicjowanego w 1871 roku przez Bismarcka tzw. kulturkampfu, pozbawiono ludność polskojęzyczną możliwości uczenia się w szkole w swoim języku macierzystym. Usunięty został całkowicie ze wszystkich szkół w tym regionie $\mathrm{z}$ wyjątkiem pomocniczego używania go w początkowym okresie nauczania religii ${ }^{2}$. Kulturkampf godził nie tylko w język polski, ale i w Kościół katolicki będący oparciem dla kultury duchowej społeczności śląskiej. W okresie wzmożonego nacisku germanizacyjnego za czasów Bismarcka rozpoczął się proces rozwoju świadomości narodowej Ślązaków. Traktowanie ludności polskojęzycznej jako obywateli gorszej kategorii pogłębiało naturalny w takich wypadkach opór. Był on tym większy, im bardziej ucisk narodowy wiązał się z uciskiem społecznym ${ }^{3}$.

\section{Polski ruch kulturalno-oświatowy}

Odpowiedzią na te poczynania stał się rozwój polskiego ruchu kulturalno-oświatowego organizowanego najczęściej przez księży lub $z$ ich inspiracji. Celem jego było mobilizowanie ludności przeciw antykościelnej polityce państwa pruskiego. W miejscowościach zamieszkałych przez ludność polską nabierał on charakteru narodowego, a język polski stawał się w owym czasie istotnym instrumentem aktywizacji społecznej. Powstały wówczas 94 organizacje katolickie skupiające ponad 11 tys. członków ${ }^{4}$. Do zrzeszających ludność polską można zaliczyć te, których nazwy zawierały słowo: „kółko”, „kasyno”. Organizowano je głównie w miastach. Celem kółek i kasyn było rozwijanie życia towarzyskiego członków i sympatyków, szerzenie między nimi oświaty, kultury i współżycia międzyludzkiego. Instrumentami, które miały służyć ich realizacji, były wycieczki, zabawy, spotkania towarzyskie, wspólne czytanie artykułów z prasy polskiej i odczyty. Część z nich nie

2 M. Pater, Polskie postawy narodowe na Ślasku w XIX wieku, cz. II (1871-1990), Wrocław 1993, s. 7; J. Kwiatek, Górnoślaska szkota ludowa na przetomie XIX i XX wieku, Opole 1987, s. 14-25.

3 Tamże, s. 75.

4 Tamże, s. 78. 
odgrywała poważniejszej roli w życiu polskim, część jednak prowadziła wielostronną pracę na rzecz uświadomienia narodowego.

W jednym z najlepiej funkcjonujących kólek - w Królewskiej Hucie (dzisiejszy Chorzów) - prowadzono od 1872 roku ożywioną akcję odczytową. W statucie jego cele określono następująco:

Po pierwsze, chce obywatelom naszego miasta dać sposobność obeznania się ze sprawami religijnymi, komunalnymi i politycznymi. Po drugie: ma być dla familii miasta i okolicy środkiem towarzyskiego skojarzenia. Dla dopięcia tego celu służyć mają: odczytywanie gazet, pism do nauki i rozrywki służących, gry towarzyskie, odczyty itp. Odczyty i rozprawy odprawiają się w każdą niedzielę. Oprócz tego zabawy uroczyste, od czasu do czasu naznaczać się mające ${ }^{5}$.

Tematyka odczytów dotyczyła polskich spraw narodowych, politycznych i ekonomicznych, np. O prawach i potożeniu ludu polskiego, O najpotrzebniejszych prawach robotniczych. Wykładowcy wywodzili się z grona polskiej inteligencji, duchowieństwa, kupców, rzemieślników i górników. Członkowie tego kółka bardzo chętnie wystawiali utwory sceniczne. Łącznie od jego powstania do 1899 roku wystawiono 60 różnych sztuk. Aktywność kulturalna i oświatowa była systematycznie ograniczana przez władze pruskie, które często uniemożliwiały organizowanie przedstawień. Działalność większości kółek zamarła na początku lat 90. XIX wieku.

Podobny charakter miało założone w 1888 roku przez młodych kupców Towarzystwo Polsko-Górnośląskie w Raciborzu, skoncentrowane głównie na działalności kulturalnej. Posiadało ono własną bibliotekę z polskim księgozbiorem liczącym ponad 300 książek, starając się upowszechniać czytelnictwo. Odbywały się odczyty, pogadanki o bardzo zróżnicowanej tematyce (historia, literatura, higiena, sprawy gospodarcze i społeczne), występy okolicznościowe z deklamacjami, śpiewem, a nawet utworzono własne kółko śpiewacze. Dwa razy w roku odbywały się przedstawienia teatralne. Wszystkie formy pracy oświatowej i kulturalnej spotykały się z bardzo dużym odzewem społecznym, o czym świadczy wysoka frekwencja sięgająca nawet 200 osób podczas spotkania ${ }^{6}$.

5 Cyt. za: M. Antonów, Dziatalnośc kulturalna polskich towarzystw nas Górnym Ślasku w drugiej potowie XIX i na początku XX wieku w świetle wspótczesnej prasy polskiej, „Studia Śląskie” 1958, t. 2, s. 632.

6 Tamże, s. 635. 
Męska młodzież śląska grupowała się w Towarzystwie św. Alojzego. Ruch Alojzjanów powstał w 1871 roku z inicjatywy ks. Norberta Bończyka w Bytomiu na fali dążeń młodych Polaków do czynnego uczestnictwa w życiu społeczno-kulturalnym i politycznym. Większość organizacji alojzjańskich została utworzona w przemysłowej części regionu, a należała do nich młodzież robotnicza i wiejska. Przyczyniła się ona do rozwoju czytelnictwa i zainteresowań młodzieży, pozwalała na poznanie tradycji narodowej i polskiej kultury. Cel ten osiągano poprzez organizowanie teatrzyków amatorskich, zabaw i wykładów. Zebrania członków odbywały się przeważnie w niedziele i święta. Wspólnie czytano na nich interesujące artykuły z polskiej prasy i polskich publikacji, wygłaszano wykłady - zarówno o treści świeckiej, jak i religijnej, Ważnym elementem pracy wychowawczej był śpiew pieśni polskich rozpoczynający i kończący każde spotkanie. Szczególne osiągnięcia odnosiły one w zakresie prowadzonej akcji teatralnej. Przygotowywano wiele różnych sztuk - czasami miejscowych autorów - które były wystawiane w licznych miejscowościach. Przedstawienia przynosiły zawsze dochód, gdyż widzowie płacili za wejście. Fundusze te wykorzystywano na pokrywanie wydatków związanych przykładowo z przygotowaniem strojów, scenografii itp. Przy niektórych towarzystwach Alojzjanów tworzono nawet orkiestry. W Piekarach posiadali Alojzjanie własną bibliotekę, a nawet „ubrania krakowskie damskie i męskie, obraz przedstawiający orła śląskiego, obraz historyczny Kościuszko pod Ractawicami. Poprzez te symbole utwierdzano się w postawach i uczuciach wspólnoty z całym narodem polskim ${ }^{7}$.

Organizacje z poszczególnych miejscowości kontaktowały się z sobą, niejednokrotnie spędzając czas wolny na zabawach, wspólnych wycieczkach. W poszczególnych miejscowościach należało do nich kilkadziesiąt, a nawet kilkaset osób ${ }^{8}$. Przykładowo w 1892 roku w Piekarach, podczas wieczorku zorganizowanego przez to towarzystwo, „śpiewano i grano różne melodie polskie, m.in. Z dymem pożarów Kornela Ujejskiego. Pieśń ta wówczas miała charakter jednego z polskich hymnów narodowych o wydźwięku także antyrosyjskim.

7 M. Pater, Polskie dążenia narodowe na Górnym Ślasku (1891-1914), Wrocław 1998, s. 238.

8 Instytut Śląski w Opolu, zbiory specjalne, A 702, t. 118, s. 2-3. 
Władze pruskie zabraniały jej upowszechniania, gdyż - jak sądzono - jej treści można było nadawać sens antyniemiecki i antypruski ${ }^{9}$. Działalność towarzystwa została przerwana „ze względów politycznych" dekretem ordynariusza wrocławskiego kardynała Georga von Koppa w 1897 roku, lecz niektóre koła nadal potajemnie funkcjonowały. Łącznie na Górnym Śląsku było 37 Towarzystw św. Alojzego do momentu ich rozwiązania ${ }^{10}$.

Ta sytuacja spowodowała, iż w roku 1898 zaczęto dawne Towarzystwa Alojzjanów przemianowywać na polskokatolickie towarzystwa młodzieżowe, towarzystwa katolickich mężów i młodzieńców. W różnych miejscowościach Górnego Śląska było 18 takich towarzystw. Ich celem było: wspólne kształcenie się i gry towarzyskie, poprzez: „czytanie pożytecznych książek i czasopism, deklamowanie, wspólny śpiew, występy muzyczne, pouczające odczyty, organizowanie towarzyskich zabaw, wspólnych wycieczek i przedstawień teatralnych”11. W „Nowinach Raciborskich” pisano:

I u nas Towarzystwo św. Alojzego zostało rozwiązane na rozkaz księdza kardynała. Byłaby jednak wielka szkoda, gdyby w tak wielkiej parafii [...] młodzież nie miała swojego towarzystwa przeznaczonego dla dobrzej oświaty i uczciwej rozrywki. W innych parafiach już się związki młodzieży utworzyły, przeto i my nie możem za drugimi pozostać. Przecież w Zaborze jest dość dzielnych młodzieńców, którzy by chętnie do związku przystąpili. Niech młodzieńcy o tej sprawie między sobą pomówią. Wkrótce się zbierzemy na zebranie i założymy Towarzystwo św. Stanisława Kostki, abyśmy się mogli pilnie przykładać do oświaty, której nam tak bardzo potrzeba ${ }^{12}$.

Ich praca kulturalno-oświatowa była traktowana jako polityczna, bowiem

w towarzystwie obwinionego zarządu tylko w języku wielkopolskim się rozprawia, i niektórzy członkowie związkowi polskie czapki narodowe (maciejówki) noszą. Towarzystwo również polskiego świętego za patro-

9 M. Pater, Polskie dqżenia narodowe na Górnym Ślasku (1891-1914), dz. cyt. s. 238.

10 M. Antonów, Dziatalnośc kulturalna polskich towarzystw nas Górnym Ślasku $w$ drugiej potowie XIX i na początku XX wieku w świetle wspótczesnej prasy polskiej, dz. cyt. s. 646.

11 Cyt.za: Cz. Mykita-Glensk, Początki ruchu mtodzieżowego na Górnym Ślasku, „Zaranie Śląskie” 1966, z. 4, s. 726.

12 „Nowiny Raciborskie” 1897, nr 137. 
na sobie obrało. [...] należy przypuszczać, że Towarzystwo to pracuje jedynie nad rozbudzaniem i pielęgnowaniem uczuć narodowo-polskich, uprawia zatem cele polityczne ${ }^{13}$.

Takie zarzuty policja pruska kierowała wobec wielu towarzystw młodzieżowych, utrudniając, bądź też uniemożliwiając im prowadzenie działalności (ograniczano się wówczas tylko do przedstawień amatorskich) ${ }^{14}$.

W latach 1890-1910 w rejencji opolskiej powstało 31 Związków Katolickich Robotników i 9 Towarzystw Górnośląskich Chrześcijańskich Przemysłowców. Związki te nie zajmowały się sprawami zawodowymi, lecz ograniczały swą działalność do celów religijnych i kulturalnych, organizując szeroką akcję odczytową i przedstawienia amatorskie. Były one zakładane i kierowane przez księży i prowadziły swoją działalność na tereniach parafii ${ }^{15}$.

Towarzystwo Górnośląskich Przemysłowców zrzeszało rzemieślników, drobnych przemysłowców, kupców i pracowników handlowych. Jego celem było „popieranie się wzajemne, pielęgnowanie języka i obyczajów polskich, uchronienie członków od złowrogich podszeptów i obudzenia w nich dobrego ducha, starania o polepszenie doli członków przez wzajemną moralną i materialną pomoc"16. W każdej z miejscowości, gdzie funkcjonowało, posiadało skromną bibliotekę (50-200 książek), a w okresie 14 lat, tj. od 1891 do 1905 roku urządziło ono 50 przedstawień teatralnych. Prowadzono również odczyty o szerokim wachlarzu problematyki obejmującej historię Polski i Śląska, zagadnienia prawne, ekonomiczne, społeczne, medyczne, aktualne problemy polityczne i społeczne, kulturę życia codziennego, geografię, sprawy religijne. Przykładowo w 1907 roku w Bytomiu zorganizowało ono wieczór kolęd, podczas którego „dzieci wygłaszały różne wierszyki związane $z$ tymi świętami, ale także

13 C. Mykita-Glensk, Początki ruchu mtodzieżowego na Górnym Ślasku, dz. cyt., s. 726.

14 M. Pater, Polskie dążenia narodowe na Górnym Ślasku (1891-1914), dz. cyt., s. $209 \mathrm{i}$ nast.

15 M. Antonów, Dziatalność kulturalna polskich towarzystw nas Górnym Ślasku w drugiej potowie XIX i na początku XX wieku w świetle wspótczesnej prasy polskiej, dz. cyt. s. 647.

16 M. Antonów, Towarzystwa przemystowców polskich w Bytomiu, Katowicach i Królewskiej Hucie w latach 1890-1914, „Kwartalnik Opolski” 1964, nr 3-4. 
o Kościuszce i Janie III Sobieskim. Potem rozdawano dzieciom prezenty świąteczne $\mathrm{w}$ postaci polskich elementarzy, polskich książek historycznych, jabłek i orzechów"17.

$\mathrm{Na}$ zjeździe delegatów Towarzystwa Przemysłowców 31 stycznia 1901 roku w Bytomiu postanowiono zwrócić się „do ludzi dobrej woli o wygłaszanie odczytów po towarzystwach lub dostarczanie tekstów, które miały być drukowane w specjalnym piśmie"18. Ta interesująca propozycja nie została jednak w praktyce zrealizowana, lecz jest dowodem na problemy z jakimi borykały się zarządy towarzystw przy organizowaniu akcji odczytowych. Wykładów odbyło się wiele, a $\mathrm{z}$ informacji zawartych $\mathrm{w}$ ówczesnej prasie znamy jedynie kilka nazwisk prelegentów, którzy w przeważającej byli członkami zarządu. Czy chętnie na nie uczęszczano? Przypuszczać należy, iż szeroki zakres omawianej problematyki był dostosowany do potrzeb, zainteresowań i możliwości odbioru słuchaczy, co zapewne wpływało ma wysoką frekwencję.

Młodzież i dorośli włączali się do prac utworzonego w 1895 roku w Bytomiu pierwszego gniazda sokolego na Górnym Śląsku, skupiającego głównie kupców i rzemieślników. Założono kilka takich gniazd w przemysłowej części Górnego Śląska, ale również w części rolniczej - w Opolu - po 1907 roku prowadziło działalność. W tym bowiem roku rozszerzono ją na zjeździe w Poznaniu o „budzenie wśród członków i wśród ludu narodowej oświaty"19. Od roku 1908 można było do nich przyjmować kobiety, tam gdzie istniały ku temu odpowiednie warunki. Towarzystwo Gimnastyczne „Sokół” głosiło ideę solidaryzmu narodowego, kultywowania polskiej tradycji oraz myśli historycznej ${ }^{20}$. Działalność koncentrowała się głównie na ćwiczeniach gimnastycznych oraz wspólnym śpiewie, deklamacjach, amatorskich przedstawieniach, odczytach i pracy oświatowej ${ }^{21}$. Dzia-

17 Cyt. za: M. Pater, Polskie dq̨̇̇enia narodowe na Górnym Ślasku (1891-1914), dz. cyt., s. 259.

18 Tamże.

19 M. Antonów, Dziatalność kulturalna polskich towarzystw nas Górnym Ślasku $w$ drugiej potowie XIX i na początku XX wieku w świetle wspótczesnej prasy polskiej, dz. cyt. s. 654.

20 M. Ponczek, Towarzystwo Gimnastyczne "Sokót” na Górnym Ślasku. Zarys dziejów 1895-1939, Katowice 1987, s. 3.

21 W. Ogrodziński, Dzieje dzielnicy ślaskiej „Sokota”, Katowice 1937, s. 59. 
łalność kulturalno-oświatowa nie miała jednak szerokiego zasięgu, bowiem szczególny nacisk kładziono na ćwiczenia gimnastyczne przygotowujące do pokazów i zlotów gniazd sokolich. Od 1905 roku spotykało to się z dezaprobatą władz pruskich, które stosowały różne formy szykan i terroru. Przykładowo, nie dopuszczano do wynajęcia sal niezbędnych do ćwiczeń oraz spotkań, zwalniano członków „Sokoła" z pracy i uniemożliwiano otrzymanie jej gdziekolwiek, nakładano mandaty karne ${ }^{22}$. Te trudne sytuacje spowodowały, że utworzone na Śląsku gniazda sokole szybko zamierały.

Szeroką pracę samokształceniową na początku XX wieku prowadziło Towarzystwo Eleusis, założone na Górnym Śląsku z inicjatywy samych robotników w styczniu 1903 roku przez docenta Uniwersytetu Jagiellońskiego, Wincentego Lutosławskiego. Głosił on hasła odrodzenia moralnego, pracy nad sobą, samokształcenia, hasła, które pozwalały w każdych warunkach społeczno-politycznych osiągać wyższy szczebel rozwoju intelektualnego. $\mathrm{Na}$ Śląsku nie była bowiem prowadzona systematyczna praca samokształceniowa.

W zaborze pruskim organizacja Elsów miała charakter tajny, nie była ruchem masowym. Liczyła około 1500 członków, obejmując swym zasięgiem wschodnie rejony Górnego Śląska. W pierwszym okresie istnienia związku były tylko trzy prawidłowo funkcjonujące ogniska - w Gliwicach, Zabrzu, Zaborzu (dzisiejsza dzielnica Zabrza). Jakie były założenia programowe Eleusis? Poprzez swoją pracę dążyło ono do „kształcenia woli i charakteru, pracy nad sobą, pogłębiania świadomości narodowej i politycznej, umacniania więzi z narodem i z kulturą narodową"23. Realizowane to miało być poprzez ćwiczenia psychofizyczne, wstrzemięźliwość i samokształcenie. Elsowie spotykali się na zebraniach, podczas których czytano fragment utworu polskiego pisarza lub o historii Polski. Często ogniska były odwiedzane przez gości z Galicji, którzy wygłaszali wykłady i - co jest bardzo interesujące - udzielali niezbędnych wskazówek z zakresu samouctwa oraz kontrolowali wyniki pracy samokształceniowej. Wskazywano uczestnikom, jakie pozycje należy czytać, jak je czytać, jakie są sposoby utrwalania wiadomości. Wskazywano metody, dzięki którym można szybko zdobyć jak największy zasób wiedzy. Konse-

22 Tamże, s. 76.

23 A. Targ, Przyczynek do historii Elsów śląskich, „Zaranie Śląskie” 1964, z. 2. 
kwencją tego był ogromny wzrost liczby samouków na Śląsku oraz w pewnym zakresie kulturalne i polityczne odrodzenie Śląska ${ }^{24}$.

\section{Organizacje kobiece}

Od początku XX wieku w działalności kulturalnej zaczęły aktywnie uczestniczyć kobiety tworzące własne stowarzyszenia. Do tego czasu były one wyłączone $\mathrm{z}$ wszelkiej działalności na mocy ustawy z 11 marca 1850 roku, która zabraniała im zrzeszania się w organizacjach politycznych, uczestniczenia w życiu publicznym, a nawet nie zezwalała na urządzanie zabaw $z$ udziałem kobiet. $W$ tym regionie pozycja kobiety była bardzo ważna, bowiem na niej spoczywał obowiązek wychowania młodego pokolenia w duchu narodowym, przygotowywania go do pielęgnowania kultury polskiej. Poprzez własne organizacje można było przyciągnąć do nich więcej kobiet i oddziaływać na szersze kręgi społeczne.

Pierwszą organizacją założoną przez kobiety na Śląsku w 1878 roku było Stowarzyszenie Matek Chrześcijańskich, a nieco później Towarzystwo Charytatywne. Celem pierwszej organizacji kobiecej na Górnym Śląsku było podejmowanie prób przeciwstawienia się tendencjom germanizacyjnym, które w okresie kulturkampfu były szczególnie nasilone. Wskazywano matkom potrzebę wychowywania młodego pokolenia w polskim i katolickim duchu. Stowarzyszeniem tym kierowali księża katoliccy, którzy w okresie polityki bismarkowskiej, zagrażającej Kościołowi, starali się przyciągnąć w obszar swoich wpływów jak największą liczbę Polaków-katolików. To stowarzyszenie utworzono w celu pogłębienia życia katolickiego, religijnego. Kobiety wspólnie odmawiały polskie modlitwy, śpiewały polskie pieśni kościelne, posługiwały się gwarą śląską w bezpośredniej komunikacji między sobą. W ten sposób te przykościelne stowarzyszenia stały się miejscem kultywowania polskości ${ }^{25}$.

Szczególną aktywność zaczęły wykazywać Górnoślązaczki od początku XX stulecia, tworząc własne stowarzyszenia. Organizacje te skupiały „kobiety śląskie w celu szerzenia i pogłębiania wśród nich

24 Tamże.

25 Historia Ślaska, t. 3, cz. 2, red. S. Michalkiewicz, Wrocław 1985, s. 287; „Świat i Życie” 1948, nr 10. 
świadomości narodowej, zaznajamiania $\mathrm{z}$ historią i literaturą polską, budzenia zamiłowania do mowy i pieśni polskiej”26. W Bytomiu w 1900 roku założyły one pierwsze Towarzystwo Kobiet na Górnym Śląsku. Sytuacja społeczna w regionie wymagała, aby powstanie tej organizacji nie było faktem jawnym, bowiem od końca XIX wieku władze pruskie powstającym organizacjom polskim narzucały status towarzystw politycznych, co wiązało się z podleganiem ścisłej kontroli policyjnej, przedstawianiem władzom statutów i listy członków. Organizacje niepolityczne nie podlegały tym krępującym przepisom. Zgodnie z poglądem władz pruskich, wszędzie tam, gdzie działalność wiązała się z polskością, organizacja miała charakter polityczny ${ }^{27}$. Celem tego towarzystwa było „wzajemne kształcenie i pouczanie w sprawach gospodarstwa domowego, zakładanie czytelń i prowadzenie działalności dobroczynnej"28. Opracowany statut organizacji nie określał jasno jej prawdziwych zadań ze względu na skomplikowaną sytuację polityczną. A właściwymi celami było: szerzenie i pogłębianie wśród członkiń świadomości narodowej, zaznajamianie z polską kulturą i literaturą, budzenie zamiłowania do mowy i pieśni ojczystej. Miało to w konsekwencji doprowadzić do świadomego przeciwstawiania się procesowi germanizacji.

Bytomskie towarzystwo prowadziło wielokierunkową działalność kulturalno-oświatową. Przeciętnie dwa razy w miesiącu odbywały się zebrania członkiń połączone z odczytami, występami artystycznymi, wspólnym śpiewem, deklamacjami, tańcami i amatorskimi przedstawieniami teatralnymi. Dla dzieci organizowano uroczystości gwiazdkowe. Po roku działalności oskarżono towarzystwo, iż jest nielegalną organizacją o charakterze politycznym. Zarzuty te udało się odeprzeć, ale członkinie były poddawane systematycznym represjom. Nie wpłynęło to na pracę tej organizacji. Wręcz przeciwnie, nawet ją wzmogło, bowiem atrakcyjny program zajęć przeciągał coraz więcej Ślązaczek. Mogły w sposób przyjemny, a zarazem pożyteczny, spędzić swój wolny czas w gronie osób o podobnych potrzebach i problemach życiowych.

26 Por. E. Sapia-Drewniak, Aktywnośc kulturalna i oświatowa kobiet na Ślasku Opolskim w latach 1922-1939, Opole 1991.

27 Historia Ślaska, t. 3, cz. 2, dz. cyt., s. 287; „Świat i Życie” 1948, nr 10.

28 S. Mazurek, Z dziejów polskiego ruchu kobiecego, Opole 1969 s. 12; taż, Nasza droga do wolności, maszynopis w Bibliotece Instytutu Śląskiego w Opolu. 
Za przykładem Bytomia również $\mathrm{w}$ innych miastach górnośląskich kobiety zaczęły się zrzeszać. W 1902 roku w Katowicach i Siemianowicach utworzono czytelnie dla kobiet „upowszechniające oświatę wśród ludu polskiego poprzez budzenie zamiłowania do polskiej książki, upowszechnianie wiedzy o kulturze polskiej”29. W 1904 roku w przemysłowej części Śląska funkcjonowało 10 organizacji kobiecych. Zwracano w nich szczególną uwagę na rozwój czytelnictwa. Współpracowano w tym zakresie z poznańskim Towarzystwem Czytelń Ludowych przysyłającym książki do czytelń kobiecych. Organizowano nielegalne kursy języka polskiego. Na prelekcjach oprócz członkiń był obecny policjant, słuchający uważnie tego, o czym ona była. Jeśli poruszano polskie kwestie narodowościowe, to zebranie „W imieniu cesarza kończono"30. Większość organizacji kobiecych była zmuszona zawiesić tę prężnie rozwijającą się działalność pod koniec 1904 roku. Było to związane z nasilającymi się szykanami i represjami pruskimi stosowanymi wobec członkiń. Ojcowie i mężowie również obawiali się, iż udział w pracy narodowej matek i żon przyniesie nieodwracalne szkody rodzinom, gdyż kobiety często były karane i prześladowane ${ }^{31}$. Po kilkuletnim okresie zastoju, koła wskrzesiły w 1912 roku swoją działalność na terenie całego Górnego Śląska.

W zakresie podniesienia poziomu świadomości narodowej szczególną rolę odegrał rozwój czytelnictwa. Było to konsekwencją zakładania czytelń, bibliotek, księgarń polskich oraz kolportażu polskich czasopism $^{32}$. Znaczącą rolę w jego rozwoju spełniło założone w 1880 roku w Poznaniu Towarzystwo Czytelń Ludowych, obejmujące zasięgiem swego oddziaływania również Górny Śląsk. „Szerzenie pożytecznych, religijne uczucia ludzi podnoszących i pouczających książek polskich i zakładanie bibliotek ludowych" było jego zadaniem. Swą aktywną działalność prowadziło na terenie całego zaboru pruskiego aż do wybuchu II wojny światowej. Na Górnym Śląsku założono 296

Teki Alojza Targa, zbiory specjalne, A 702, t. 121; P. Porwol, Dziatalność narodowa Karola Piechy z Zabrza, Kroniki miasta Zabrza 1978; A Grajpel, Z dziejów tajnej oświaty polskiej w Zabrzu, Kroniki miasta Zabrza 1978.

31 „Świat i Życie” 1948, nr 6.

32 Życie polskie w Świętochtowicach na poczatku XX wieku, Instytut Śląski w Opolu. Teki Alojza Targa, zbiory specjalne, A 702, t. 118. 
bibliotek. Znajdowały się w nich książki polskich autorów, jak również utwory literackie zakazane przez władze pruskie. Ich tematyka dotyczyła kwestii religijnych, historycznych, moralnych, obyczajowych $^{33}$. Władze pruskie prowadziły skrupulatną cenzurę zawartości księgozbiorów, stąd też nie było w nich książek o ostrzejszych akcentach politycznych i narodowych. Sytuacja ta nie uchroniła jednak towarzystwa od prześladowań ze strony władz pruskich, procesów o książkę itp. Założone na Górnym Śląsku biblioteki prowadzili prości, niewykształceni ludzie, którzy nie byli wynagradzani za pracę oświatową, traktujący ją jako zaszczyt i honor, nie zrażając się do niej, mimo częstych przesłuchań na policji i rewizji w domach ${ }^{34}$.

Polskie słowo przyczyniało się do podkreślania i pogłębiania więzi narodowej. Pozwalało na budowanie szacunku i miłości do własnej mowy, a tym samym i do własnej przeszłości, obyczajów oraz co było na przełomie wieków bardzo ważne - własnej odrębności narodowej. Język polski wówczas traktowano jako istotny element narodowej kultury duchowej, czego przejawem był właśnie rozwój czytelnictwa. $Z$ roli słowa $\mathrm{w}$ procesie integracji narodowej zdawali sobie sprawę inicjatorzy działalności pozaszkolnej, dla których rozwój bibliotek był istotnym elementem budowania systemu polskiej edukacji pozaszkolnej.

W tworzonych na Górnym Śląsku na przełomie XIX i XX wieku polskich organizacjach szczególną wagę przywiązywano do kultywowania polskiej pieśni. Ona urozmaicała spotkania i wszystkie formy pracy oświatowej. Śpiew zbiorowy początkowo kultywowały kasyna i kółka, towarzystwa alojzjanów, towarzystwa górnośląskich przemysłowców, katolickich robotników, kobiece. Pierwszym, najstarszym samoistnym zespołem śpiewaczym w regionie był chór „Lutnia”, założony w Opolu w 1893 roku, ale istniał on tylko kilka miesięcy. Rok później w przemysłowej części Śląska, w Bogucicach (dzisiejsza dzielnica Katowic), założono chór również pod nazwą „Lutnia”. Podobnie i w innych miastach takowe zespoły śpiewacze organizowano.

W 1908 roku pruska ustawa utrudniająca organizowanie polskich wieców i publicznych zebrań ułatwiała powstawanie towarzystw

\footnotetext{
33 J. Wróblewski, Polskie biblioteki ludowe w zaborze pruskim i na terenie Rzeszy Niemieckiej w latach 1843-1939, Olsztyn 1975, s. 62 i nast.

34 Tamże.
} 
apolitycznych o lokalnym zasięgu działania, gdyż uwalniała je od kontroli władz policyjnych. Ta ustawa, chociaż w swoim zamiarze była skierowana przeciw polskim organizacjom, przyczyniła się do powstania i rozwoju polskich chórów ${ }^{35}$. Jak pisze Jan Fojcik,

Chóry same uważały się początkowo za organizacyjnie apolityczne, praktyka jednak i liczne rozprawy sądowe niebawem udowodniły, że towarzystwa śpiewacze odgórnie były zaliczone do organizacji politycznych, i tym samym poddane kontroli i przewidzianym w nowej ustawie ograniczeniom. Przeszkody te nie zahamowały już jednak rozpędu, z jakim się po raz wtóry zabrano do organizowania chórów ${ }^{36}$.

Między 1908 a 1910 rokiem powstało kilkanaście chórów. Stały się one zalążkiem Związku Śląskich Kół Śpiewaczych, który stał się poważną organizacją ludności śląskiej. Należeli do nich członkowie organizacji zawodowych i oświatowych, czyli głównie robotnicy.

\section{Zakończenie}

Trudno w krótkim opracowaniu wspomnieć o wszystkich towarzystwach prowadzących pracę kulturalno-oświatową, bowiem było ich ponad 200 w okresie od 1889 roku do wybuchu I wojny światowej. Przedstawione w powyższym tekście towarzystwa prowadziły intensywną pracę kulturalno-oświatową, oddziałującą na szersze kręgi śląskiej społeczności, często stanowiąc inspirację do zakładania organizacji w innych miejscowościach. Działalność kulturalno-oświatowa na przełomie XIX i XX wieku pełniła funkcję kompensacyjną. Wypełniała lukę w narodowej edukacji, która powstała na skutek braku szkolnictwa polskiego na Górnym Śląsku. Działające w tym regionie organizacje stawiały sobie jako cel główny obronę polskości na terenach zamieszkałych przez ludność polskojęzyczną. Realizowano to poprzez upowszechnianie wiedzy, inspirowanie różnych form pracy kulturalnej i oświatowej. W ten sposób przeciwstawiano się wpływom niemieckim. Istotny wydaje się fakt, że olbrzymie rozproszenie organizacji na terenie całego Górnego Śląska miało korzystne znaczenie dla budzenia i utrwalania świadomości narodowej, gdyż umożliwiało udział w ich pracach licznym rzeszom

35 J. Fojcik, Materiaty do ruchu śpierwaczego na Ślasku, Katowice 1961, s. 23.

36 Tamże, s. 25. 
Górnoślązaków z różnych warstw społecznych. To właśnie towarzystwa robotników, przemysłowców, kobiece, śpiewacze, czytelnicze, polskokatolickie przyczyniły się do podniesienia świadomości przynależności narodowej ludności tej prowincji, pozwalały na poszerzenie wiedzy uczestników z zakresu historii narodu polskiego, co oddźwięk znalazło w zaangażowaniu politycznym ludności w latach późniejszych, kiedy decydowała się przynależność regionu do nowo powstałego państwa polskiego.

\section{Bibliografia}

\section{Źródła archiwalne i drukowane}

Instytut Śląski w Opolu, Teki Alojza Targa, zbiory specjalne, A 702, t.118, 121.

Mazurek S. Nasza droga do wolności, maszynopis w Bibliotece Instytutu Śląskiego w Opolu.

„Nowiny Raciborskie” 1897 nr 137.

„Świat i Życie” 1948 nr 6 i 10.

\section{Opracowania}

Antonów M., Dziatalnośc kulturalna polskich towarzystw nas Górnym Ślasku w drugiej potowie XIX i na poczatku XX wieku w śrwietle wspótczesnej prasy polskiej, „Studia Śląskie” 1958, t. 2.

Antonów M., Towarzystwa przemystowców polskich w Bytomiu, Katowicach i Królewskiej Hucie w latach 1890-1914, „Kwartalnik Opolski”, 1964 nr 3-4.

Fojcik J., Materiaty do dziejów ruchu śpiewaczego na Ślasku, Wydawnictwo Śląsk, Katowice 1961.

Grajpel A., Z dziejów tajnej oświaty polskiej w Zabrzu, Kroniki miasta Zabrza 1978.

Historia Ślaska, t. 3, cz. 2, red. S. Michalkiewicz, Zakład Narodowy im. Ossolińskich, Wrocław 1985.

Jonca K., Polityka socjalna Niemiec w przemyśle ciężkim Górnego Ślaska, Wydawnictwo Śląsk, Katowice 1966.

Kwiatek J., Górnoślaska szkota ludowa na przetomie XIX i XX wieku, Instytut Śląski w Opolu, Opole 1987.

Mazurek S., Z dziejów polskiego ruchu kobiecego, Instytut Śląski w Opolu, Opole 1969. 
Mykita-Glensk C., Początki ruchu mtodzieżowego na Górnym Ślasku, „Zaranie Śląskie”1966, z. 4.

Ogrodziński W., Dzieje dzielnicy ślaskiej „Sokota”, Związek Polskich Towarzystw Gimnastycznych „Sokół”, Katowice 1937.

Pater M., Polskie dążenia narodowe na Górnym Ślasku (1891-1914), Centrum Badań Śląskoznawczych i Bohemistycznych Uniwersytetu Wroclawskiego, Wrocław 1998.

Pater M., Polskie postawy narodowe na Ślasku w XIX wieku, cz. II (18711990), „Sudety”, Wrocław 1993.

Ponczek M., Towarzystwo Gimnastyczne "Sokót” na Górnym Śląku. Zarys dziejów 1895-1939, Muzeum Śląskie, Katowice 1987.

Porwol L., Dziatalność narodowa Karola Piechy z Zaborza, Kroniki miasta Zabrza 1978.

Ręgorowicz L., Wspomnienia śląskie i poznańskie, Instytut Śląski w Opolu, Opole 1976.

Sapia-Drewniak E., Aktywność kulturalna i oświatowa kobiet na Śląsku Opolskim w latach 1922-1939, Związek Górnośląski, Opole 1991.

Targ A., Przyczynek do historii Elsów śląskich, „Zaranie Śląskie” 1964, z. 2.

Wróblewski J., Polskie biblioteki ludowe w zaborze pruskim i na terenie Rzeszy Niemieckiej w latach 1843-1939, Ośrodek Badań Naukowych im. Wojciecha Kętrzyńskiego, Olsztyn 1975.

\section{ADRES DO KORESPONDENCJ}

Prof. dr hab. Eleonora Sapia-Drewniak

Uniwersytet Opolski

Wydział Historyczno-Pedagogiczny, Instytut Nauk Pedagogicznych sapia@uni.opole.pl 